\title{
KUALITAS PELAYANAN PERPUSTAKAAN KELILING DI DINAS PERPUSTAKAAN DAN KEARSIPAN KABUPATEN KOTAWARINGIN TIMUR
}

\author{
1 Binti Azizatun Nafi'ah, ${ }^{2}$ Saffa Indah Salsabila, ${ }^{3}$ Laili Khikmawati, ${ }^{4}$ Shalenia Anggi Christy \\ 1,2,3,4 Program Studi IImu Administrasi Publik Fakultas Ilmu Sosial dan Ilmu Politik \\ Universitas Pembangunan Nasional "Veteran" Jawa Timur \\ 1,2,3,4 Administrasi Publik Fakultas IImu Sosial dan IImu Politik UPN "Veteran" Jawa Timur; \\ Email: binti.azizatun.adneg@upnjatim.ac.id, saffaindah@gmail.com, \\ lailikhikmawati849@gmail.com, shalenia.anggi@gmail.com \\ Surabaya, 60294, Indonesia
}

\begin{abstract}
The purpose of this research is to discover The Service Quality of Mobile Library of Library and Archives Department of East Kotawaringin Regency in providing services. The research used a method named qualitative descriptive. The data was collected through observation, interview, and documentation. The theory used was the dimension of service quality by Zeitahml, Parasuraman, and Berry. The results of this study showed that the service quality of mobile library services of Library and Archives Department of East Kotawaringin Regency is considered good. In the tangibles dimension, it is proven by the presentable appearance of the personnel and the availability of well-equipped facilities. The reliability dimension includes the ability and the reliability of the personnel in providing the promised service. Responsiveness includes the promptness and the willingness to provide an immediate and accurate service when responding to visitors' requests. Assurance includes the ability and courtesy of the personnel in assuring the visitors, to create a positive perception in visitors. Lastly, empathy is associated with the caring attention that the personnel give when providing attentive service to the visitors. Even though the service quality of the mobile library of library and archives department of East Kotawaringin Regency is good enough, it is necessary to improve the tangibles (physical evidence) and reliability (trust) dimensions.
\end{abstract}

Keywords: Literacy; Mobile library; Public Services; Quality Services

\begin{abstract}
Abstrak
Tujuan dari penelitian ini untuk mengetahui Kualitas Pelayanan Perpustakaan Keliling Di Dinas Perpustakaan dan Kearsipan Kabupaten Kotawaringin Timur dalam memberikan pelayanan. Penelitian ini menggunakan metode penelitian deskriptif kualitatif. Pengumpulan data dilakukan melalui observasi, wawancara, dan dokumentasi. Teori yang digunakan yaitu teori dimensi kualitas pelayanan dari Zeithaml, Parasuraman, dan Berry. Hasil dari penelitian ini menunjukan bahwa kualitas pelayanan perpustakaan keliling Dinas Perpustakaan dan Kearsipan Kabupaten Kotawaringin Timur sudah cukup baik yang dilihat dari dimensi tangibles meliputi penampilan petugas yang sudah sopan dan rapi serta tersedianya fasilitas yang cukup lengkap, reliability meliputi kemampuan dan keandalan petugas untuk menyediakan pelayanan yang terpercaya, responsiveness meliputi ketanggapan dan kepedulian petugas untuk memberikan pelayanan secara cepat, tepat, dan tanggap terhadap keinginan pengunjung, assurance meliputi kemampuan dan keramahan petugas dalam meyakinkan pengunjung sehingga menimbulkan persepsi positif kepada pengunjung, dan emphaty yang berkaitan dengan kepedulian petugas dalam pemberian perlakuan penuh perhatian kepada pengunjung. Walaupun kualitas pelayanan perpustakaan keliling Dinas Perpustakaan dan Kearsipan Kabupaten Kotawaringin Timur sudah cukup baik. Namun masih perlunya perbaikan terkait dimensi tangibles (bukti fisik) dan pada dimensi reliability (kepercayaan).
\end{abstract}

Keywords: Kualitas Pelayanan; Literasi; Pelayanan Publik; Perpustakaan Keliling 


\section{Journal Publicuho}

ISSN2621-1351 (online), ISSN 2685-0729 (print)

Volume 4 Number 2 (May-July), (2021)pp. 400-410

Accredited SINTA SK.NOMOR 28/E/KPT/2019

Open Access at:http://ojs.uho.ac.id/index.php/PUBLICUHO/index

DOI: 10.35817/jpu.v4i2.18049

\section{PENDAHULUAN}

Perkembangan zaman yang semakin maju, membuat pemerintah dituntut untuk meningkatkan pelayanannya terhadap publik. Tuntutan tersebut menjadi sebuah keharusan untuk pemerintah. Hakikat pelayanan publik adalah pemberian pelayanan prima kepada masyarakat yang merupakan perwujudan kewajiban aparatur Pemerintah sebagai abdi masyarakat (Ratminto \& Winarsih, 2013) dalam (Melinda, M., Syamsurizaldi, \& Muhammad, I. K., 2020). Berdasarkan amanat yang terkandung dalam Pembukaan Undang-Undang Dasar Negara Republik Indonesia Tahun 1945 pada Alinea ke-4, yang menyebutkan bahwa salah satu tujuan Negara Indonesia ialah mencerdaskan kehidupan bangsa. Melalui amanat yang terkandung pada Pembukaan Undang-Undang Dasar Negara Republik Indonesia Tahun 1945 itu, pemerintah pun wajib memberikan layanan atas pengetahuan dan informasi kepada masyarakat. Pemberian layanan atas pengetahuan dan informasi wajib dilakukan bagi pemerintah agar dapat menanamkan budaya literasi pada masyarakat. Budaya literasi penting untuk meningkatkan kecerdasan dan pengetahuan bangsa.

Menurut (Permatasari, 2015) dalam (Laksmi, 2020) Semakin banyak penduduk suatu wilayah yang bersemangat dalam mencari dan meningkatkan ilmu pengetahuan, maka akan semakin tinggi peradabannya. Menanamkan budaya literasi pada masyarakat tidaklah mudah. Salah satu daerah yang tergolong mempunyai tingkat literasi rendah yaitu Provinsi Kalimatan Tengah. Menurut riset yang dilakukan Pusat Penelitian Kebijakan Pendidikan dan Kebudayaan (Puslitjakbud) melalui "Indeks Aktivitas Literasi Membaca 34 Provinsi" mengenai rata-rata indeks aktivitasi literasi membaca (Alibaca) menunjukan bahwa aktivitas literasi membaca di Kalimantan Tengah pada Tahun 2019 berada di peringkat ke-24 dari total 34 Provinsi.

Dalam penelitian tersebut dapat terlihat bahwa aktivitasi literasi membaca Provinsi Kalimantan Tengah masih berada di level rendah, yakni 33,86. Melalui rata-rata indeks Alibaca tersebut pula, dapat diketahui bahwa hasil rata-rata indeks Alibaca Provinsi Kalimantan Tengah masih jauh berada dibawah rata-rata indeks Alibaca Provinsi Kalimantan Selatan yang mencapai yakni, 37,00. Salah satu Kabupaten di Kota Sampit Kalimantan Tengah yaitu Kabupaten Kotawaringin Timur, menjadi salah satu kabupaten yang memiliki tingkat budaya literasi rendah, hal tersebut didasarkan dari data pengunjung perpustakaan umum Kabupaten Kotawaringin Timur yang jumlah pengunjungnya mengalami penurunan signifikan dari tahun 2018 dengan jumlah 11.921 orang yang kemudian pada tahun 2019 jumlah pengunjung hanya mencapai mencapai 8.588 orang saja. Penurunan jumlah pengunjung tersebut mencapai sebesar 3.333 orang. Rendahnya 
tingkat kesadaran masyarakat Kabupaten Kotawaringin Timur akan pentingnya budaya literasi tersebut pun tentu sangat disayangkan.

Untuk menanggulangi permasalahan itu, Dinas Perpustakaan dan Kearsipan Kabupaten Kotawaringin Timur memanfaatkan kembali inovasi pelayanan perpustakaan keliling yang telah ada sejak tahun 2009 lalu sebagai sarana promosi dalam meningkatkan budaya literasi masyarakat. Perpustakaan keliling merupakan salah satu inovasi yang terdapat di Dinas Perpustakaan dan Kearsipan Kabupaten Kotawaringin Timur, inovasi itu sendiri dilaksanakan sebagai upaya dalam rangka memberikan pelayanan atas pengetahuan dan informasi untuk masyarakat serta sebagai perwujudan dalam meningkatkan pelayanan publiknya. Menurut (Arif, L., 2019) Pelayanan publik sebagai salah satu produk kebijakan dari pemerintah dalam pelaksanaannya haruslah tetap mengacu pada tujuan kerangka besar yaitu untuk mewujudkan kesejahteraan masyarakat. Dinas Perpustakaan dan Kearsipan Kabupaten Kotawaringin Timur dalam pelayanan perpustakaan kelilingnya, memberikan pelayanan dengan menyediakan bahan pustaka yang akan ditawarkan kepada masyarakat.

Namun dalam pelayanannya, terdapat beberapa permasalahan yang ditemukan. Permasalahan tersebut diantaranya seperti :

1. Pemustaka (pengunjung) masih perlu mencari tempat yang nyaman untuk melaksanakan kegiatan membacanya, selain itu tidak dapat meminjam koleksi buku untuk dibawa pulang sehingga hal tersebut membuat pemustaka kecewa karena merasa kurang puas untuk membaca.

2. Ketika berkunjung, pemustaka wajib mengisi buku kunjungan yang ditulis dengan manual di buku kunjungan yang disediakan. Pemustaka merasa direpotkan untuk mengisi buku kunjungan tersebut karena masih ditulis secara manual.

3. Pada jam istirahat layanan, pemustaka merasa kurang nyaman ketika pemustaka sedang mencari buku koleksi yang ingin mereka baca atau yang sedang mereka baca, akan tetapi mereka harus menghentikan aktivitasnya tersebut pada saat petugas pelayanan istirahat dan waktu tutup perpustakaan keliling. Pemustaka berharap agar perpustakaan keliling dapat dibuka lebih lama dan pengunjung bisa membaca buku di dalam perpustakaan keliling lebih lama lagi, mengingat buku koleksi yang disediakan tidak dapat dipinjam.

Menurut (Goetsch \& Davis, 2009:20) dalam (Salsabila, A. K., \& Ertien, R. N., 2019) mendefinisikan kualitas pelayanan sebagai suatu kondisi dimana yang berhubungan dengan produk, jasa, manusia, proses dan lingkungan yang memenuhi atau melebihi harapan. Selanjutnya (Zeithaml \& Bitner, 2003: 17) dalam (K., B. C., \& Mecca, A., 2017), mendefinisikan kualitas pelayanan sebagai "Excellent, superior atau keunggulan pelayanan yang diterima oleh pelanggan sesuai dengan yang diharapkan oleh pelanggan". (Kotler, 


\section{Journal Publicuho}

ISSN2621-1351 (online), ISSN 2685-0729 (print)

Volume 4 Number 2 (May-July), (2021)pp. 400-410

Accredited SINTA SK.NOMOR 28/E/KPT/2019

Open Access at:http://ojs.uho.ac.id/index.php/PUBLICUHO/index

DOI: 10.35817/jpu.v4i2.18049

2005) dalam (Arif, L., 2019) juga berpendapat bahwa kualitas adalah ciri dan sifat dari suatu pelayanan berpengaruh terhadap kemampuan untuk memuaskan kebutuhan yang nyata.

Menurut Dwiyanto (2006:56) yang dikutip dari La Ode Muhammad Elwan. (2019) bahwa pemberian pelayanan publik oleh aparatur pemerintah kepada masyarakat (publik) merupakan perwujudan dan fungsi aparatur negara sebagai pelayan masyarakat (abdi), disamping sebagai abdi negara. Dalam konteks ini masyarakatlah sebagai aktor utama (pelaku) pembangunan, sedangkan pemerintah berkewajiban untuk mengarahkan, membimbing serta menciptakan suasana yang menunjang kegiatan-kegiatan dari masyarakat tersebut. Pada kondisi ini aparatur negara dituntut untuk lebih mampu memperbaiki kinerjanya (pelayanan prima) dan diharapkan lebih mampu merumuskan konsep atau menciptakan iklim yang kondusif, sehingga sumber daya pembangunan dapat menjadi pendorong percepatan terwujudnya masyarakat yang mandiri dan sejahtera. Pelayanan yang telah menunjuk kepada aturan formal dianggap telah memenuhi sendisendi pelayanan yang baik dan aparat pelayanan dianggap telah konsisten dalam menerapkan aturan hukum pelayanan, (La Ode Muhammad Elwan, 2019)

Melalui beberapa definisi kualitas pelayanan publik yang diberikan para ahli diatas, penulis menyimpulkan bahwa "Kualitas pelayanan publik merupakan tingkat layanan atau mutu layanan dari pihak penyelenggara pelayanan dalam memberikan layanan kepada pelanggan akan kebutuhan mereka baik terkait produk maupun jasa yang berdasarkan kesamaan layanan dengan harapan serta kenyataan yang didapatkan oleh pelanggan tersebut". Menurut Zeithaml, Parasuraman, dan Berry dalam (Arista, 2019) aspek-aspek dimensi kualitas pelayanan terbagi menjadi lima, yaitu meliputi:

1. Tangibles (bukti fisik),

2. Reliability (kepercayaan),

3. Responsiveness (daya tanggap),

4. Assurance (jaminan),

5. Emphaty (empati).

Agustina, S., \& Adi, K. (2020) dalam jurnalnya "Kualitas Pelayanan Perpustakaan Keliling di Perpustakaan Daerah Kabupaten Jember", menjelaskan mengenai kualitas pelayanan perpustakaan yang baik dapat dilakukan dengan memperbaiki kualitas petugas untuk memberikan kepuasan kepada pengunjung. Penelitian yang dilakukan oleh Agustina, S., \& Adi, K. tersebut relevan dengan topik penelitian yang peneliti kerjakan, mengenai kualitas pelayanan perpustakaan untuk memberikan kepuasan terhadap pengunjung. Melalui hal tersebut adapun yang menjadi tujuan dari penelitian ini yaitu ialah untuk mengetahui, mendeskripsikan dan menganalisis penyelenggaraan pelayanan Perpustakaan Keliling di Dinas Perpustakaan dan Kearsipan Kabupaten Kotawaringin Timur sebagai upaya untuk 
ISSN2621-1351 (online), ISSN 2685-0729 (print

Volume 4 Number 2 (May-July-2021) pp.400-410

meningkatkan kualitas pelayanan publiknya. Permasalahan ini perlu diteliti serta dipelajari lebih lanjut karena sangat penting untuk mengetahui sebaik apa penyelenggaraan perpustakaan keliling tersebut dilakukan sehingga pelayanan yang dilakukan tersebut dapat memenuhi kebutuhan masyarakat akan pengetahuan dan informasi. Dari penjelasan singkat tersebut, penulis tertarik untuk mengangkat penelitian dengan judul "Kualitas Pelayanan Perpustakaan Keliling Di Dinas Perpustakaan Dan Kearsipan Kabupaten Kotawaringin Timur."

\section{METODOLOGI}

Jenis penelitian ini menggunakan pendekatan kualitatif dan tipe penelitian deskriptif. Nawawi dalam Aminullah \& Rifqoh, (2021) berpendapat bahwa metode desktiptif bisa juga diartikan sebagai prosedur untuk memecahkan sebuah masalah yang di identifikasi dengan penggambaran keadaan dari subyek maupun objek penelitian yang didasarkan pada fakta yang timbul. Teknik pendekatan kualitatif dipilih karena penelitian ini dilakukan dengan analisis induktif dari data yang peneliti dapatkan mengenai fenomena penyelenggaraan Perpustakaan Keliling Dinas Perpustakaan Dan Kearsipan Kabupaten Kotawaringin Timur dilapangan yang selanjutnya peneliti tuangkan dalam bentuk penjelasan. Melalui metode tersebut, ditujukan agar penelitian memperoleh data atau informasi yang komprehensif sesuai dengan keadaan nyata di lapangan mengenai pelaksanaan pelayanan perpustakaan keliling di Dinas Perpustakaan Dan Kearsipan Kabupaten Kotawaringin Timur. Dalam penelitian ini, peneliti juga menganalisis dengan menggunakan teori aspek-aspek dimensi kualitas pelayanan yang meliputi: 1) Tangibles (bukti fisik), 2) Reliability (kepercayaan), 3) Responsiveness (daya tanggap), 4) Assurance (jaminan), 5) Emphaty (empati). Penelitian ini menggunakan dua sumber data yang bersifat primer dan sekunder. Sehingga, teknik pengumpulan data penelitian ini dilakukan melalui wawancara yang peneliti lakukan dengan serta studi literatur dengan penelusuran yang diperoleh dari buku, jurnal, dan data dari Dinas Perpustakaan Dan Kearsipan Kabupaten Kotawaringin Timur.

\section{HASIL DAN PEMBAHASAN}

Pelayanan publik pada prinsipnya merupakan seluruh bentuk jasa pelayanan, yang terdapat baik dalam bentuk jasa publik ataupun barang publik yang telah menjadi tanggung jawab serta keharusan instansi pemerintah untuk menyediakannya kepada masyarakat. Namun dalam pelaksanaan tanggung jawab tersebut, pemerintah tentu harus dapat memenuhi harapan-harapan serta impian masyarakat hingga dapat menghasilkan kepuasan kepada masyarakat. Kualitas pelayanan yang baik merupakan sebuah keharusan yang dimiliki sebuah lembaga pemerintah. Salah satunya seperti yang dijalankan oleh Dinas Perpustakaan dan Kearsipan Kabupaten Kotawaringin Timur dalam 


\section{Journal Publicuho}

ISSN2621-1351 (online), ISSN 2685-0729 (print)

Volume 4 Number 2 (May-July), (2021)pp. 400-410

Accredited SINTA SK.NOMOR 28/E/KPT/2019

Open Access at:http://ojs.uho.ac.id/index.php/PUBLICUHO/index

DOI: 10.35817/jpu.v4i2.18049

upaya menciptakan kecerdasan masyarakat melalui layanan perpustakaan keliling. Adapun hasil yang diperoleh peneliti dari penelitian fenomena penyelenggaraan pelayanan Perpustakaan Keliling Dinas Perpustakaan Dan Kearsipan Kabupaten Kotawaringin Timur yang ditujukan untuk mengetahui kualitas pelayanan publik di Dinas Perpustakaan dan Kearsipan Kabupaten Kotawaringin Timur yang disajikan berdasarkan aspek-aspek dimensi kualitas pelayanan publik berikut :

\section{a. Tangibles (Bukti Fisik)}

Tangibles merupakan unsur yang sangat berperan penting dalam kualitas suatu pelayanan publik. Tangibles disini bisa mencakup sarana dan prasarana. Aminullah \& Rifqoh, (2021) menyebutkan bahwa satu diantara aspek kualitas pelayanan yang wajib untuk diperbaiki dalam upaya meningkatkan kualitas pelayanan adalah fasilitas pelayanan. Dari penelitian yang telah dilakukan, dapat dilihat hasilnya yaitu Pada dimensi tangibles pengunjung merasa puas dengan penampilan petugas yang berpenampilan sopan dan rapi dengan menggunakan pakaian dinas sesuai dengan aturan yang berlaku. Bukti fisik lainnya yang meliputi sarana serta prasarana yang ada di perpustakaan keliling Dinas Perpustakaan dan Kearsipan Kabupaten Kotawaringin Timur adalah terdiri dari Rak Buku, Buku Bacaan, dan Buku Tamu Pengunjung. Fasilitas yang dimiliki tersebut dianggap masih kurang lengkap.

Masih terdapatnya masalah-masalah penting yang mencakup pada sarana dan prasarana di perpustakaan keliling Dinas Perpustakaan dan Kearsipan Kabupaten Kotawaringin Timur yaitu, kurang tersedianya tenda baca untuk pengunjung, sistem layanan baca perpustakaan keliling sendiri dilakukan di luar ruangan (open acces) yang dalam pelaksanaan pelayanannya perlunya memperhatikan terhadap perubahan cuaca. Kurang tersedianya kursi baca yang cukup serta kurang tersedianya meja baca untuk pengunjung mendapatkan kenyamanan dalam kegiatan membaca mereka di perpustakaan keliling. Kurang tersedianya komputer untuk mempermudah pekerjaan petugas, hingga masih kurang lengkapnya koleksi buku yang tersedia. Kurangnya saranan dan prasarana tersebut menyebabkan menurunnya kenyaman pengunjung perpustakaan dalam berkegiatan di perpustakaan keliling.

\section{b. Reliability (Kepercayaan)}

Pada dimensi reliability mencakup kemampuan serta kehandalan petugas dalam menyajikan pelayanan yang terpercaya. Untuk dimensi ini, pengunjung merasa kebutuhannya cukup terpenuhi karena petugas dapat secara cepat dan cermat dalam memberikan pelayanan terhadap pengunjung. Selain itu, petugas juga memiliki kemampuan yang cukup baik dalam melayani pengunjung. Hal ini dilihat dari pengetahuan petugas dalam menjawab pertanyaan baik mengenai koleksi buku maupun 
prosedur layanan pendaftaran keanggotaan yang dijawab dengan cukup baik dan jelas kepada pengunjung.

Dalam pelayanan penyediaan bahan bacaan, Dinas Perpustakaan dan Kearsipan Kabupaten Kotawaringin Timur telah berupaya untuk menyediakan koleksi-koleksi pustaka yang sesuai dengan kebutuhan masyarakat. Dalam hal tersebut, apabila tidak terdapat koleksi buku yang sesuai permintaan pengunjung, petugas dengan sigap membantu memberikan saran kepada pengunjung untuk membaca buku lain yang tersedia di perpustakaan. Petugas juga memiliki kehandalan dalam menempatkan koleksi buku sesuai dengan urutannya, sehingga koleksi buku yang ada dapat tersusun dengan rapi.

Disamping itu, dalam pelayanannya Dinas Perpustakaan dan Kearsipan Kabupaten Kotawaringin Timur memiliki standar pelayanan perpustakaan jelas yang tertuang dalam SOP-AP (Standar Operasional Prosedur Administrasi Pemerintahan) Dinas Perpustakaan dan Kearsipan Kab. Kotim pada Tahun 2019. Pelaksanaan standar pelayanan yang dilakukan petugas perpustakaan dapat dikatakan cukup baik, namun masih belum sepenuhnya dapat memenuhi kebutuhan pengunjung, hal itu terjadi karena kurangnya pustakawan, dan ketika ingin meminjam buku harus mendatangi dinas perpustakaannya terlebih dahulu karena hal tersebut sesuai dengan ketetapan prosedur yang ada, serta walaupun Dinas Perpustakaan dan Kearsipan Kabupaten Kotawaringin Timur telah memberikan pelatihan dan pendidikan perpustakaannya. Akan tetapi, masih kurangnya pendidikan dan pelatihan petugas secara intensif dalam bidang perpustakaan membuat wawasan petugas perpustakaan mengenai pelayanan perpustakaan belum sepenuhnya luas, sehingga petugas masih mengalami beberapa kendala, selain itu disebabkan karena latar belakang pendidikan petugas ada yang bukan dari jurusan IImu Perpustakaan.

\section{c. Responsiveness (Daya Tanggap)}

Pada dimensi responsiveness mencakup ketanggapan dan kepedulian petugas untuk memberikan pelayanan yang cepat tanggap, dan tepat terhadap keinginan pengunjung. Petugas memiliki ketanggapan dan kepedulian yang baik dalam memberikan pelayanan yang cepat dan tepat apabila terdapat pengunjung yang merasa kesulitan atau kebingungan dalam layanan yang tersedia, misalnya seperti kesulitan atau kebingungan dalam mencari koleksi buku yang ingin dibaca. Daya tanggap petugas dapat dilihat dengan kecepatan petugas dalam merespon pengunjung yang ingin mendapatkan pelayanan.

Selain itu, ketika ada ajuan permintaan layanan dari pengunjung, petugas langsung menindaklanjuti dengan cukup baik permintaan layanan dari pengunjung tersebut apabila sesuai dengan jenis layanan yang tersedia, seperti misalnya permintaan pendaftaran keanggotaan perpustakaan keliling, petugas pun akan memberikan arahan atau informasi mengenai prosedur-prosedurnya atau mengenai permintaan referensi buku, apabila 


\section{Journal Publicuho}

ISSN2621-1351 (online), ISSN 2685-0729 (print)

Volume 4 Number 2 (May-July), (2021)pp. 400-410

Accredited SINTA SK.NOMOR 28/E/KPT/2019

Open Access at:http://ojs.uho.ac.id/index.php/PUBLICUHO/index

DOI: 10.35817/jpu.v4i2.18049

referensi buku yang diminta pengunjung tersedia maka petugas akan memberikan referensi buku seperti yang diminta oleh pengunjung tersebut. Namun, apabila permintaan layanan yang diajukan pengunjung tidak tersedia, petugas akan siap tanggap untuk mengarahkan dan memberikan saran atau ide lain kepada pengunjung untuk membaca buku-buku favorit yang tersedia di perpustakaan keliling.

Disamping itu, tidak adanya komputer yang tersedia dalam pelayanan perpustakaan keliling Dinas Perpustakaan dan Kearsipan Kabupaten Kotawaringin Timur membuat hal tersebut cukup menjadi sebuah kendala bagi petugas perpustakaan keliling untuk mencari koleksi buku. Hal tersebut menyebabkan pengunjung perlu mencari secara manual. Namun, belum menjadi kendala untuk proses pelayanan peminjaman buku yang membutuhkan alat barcode, karena buku yang ada tidak untuk dipinjamakan akan tetapi hanya untuk dibaca.

\section{d. Assurance (Jaminan)}

Pada dimensi assurance mencakup kemampuan dan keramahan petugas dalam meyakinkan pengunjung sehingga menimbulkan persepsi positif kepada pengunjung. Menurut Yuningsih, (2016) menjelaskan bahwa pada dimensi assurance atau jaminan dapat dilihat ukurannya melalui beberapa faktor yaitu jaminan keamanan dan juga kenyamanan dari pelayanan yang diberikan, mampu memberikan kepercayaan terhadap pelayanan dengan selalu bersikap ramah, bersikap sopan dan santun dalam memberikan pelayanan.

Dari hasil penelitian, diketahui dalam dimensi ini petugas telah memenuhi jaminan keramahan dalam melayani pengunjung. Hal tersebut dilihat dari petugas dapat menyampaikan serta memberikan pelayanan kepada pengunjung dengan ramah, sopan, dan menyenangkan. Hal ini membuat pengunjung menilai bahwa petugas perpustakaan keliling Dinas Perpustakaan dan Kearsipan Kabupaten Kotawaringin Timur sudah cukup baik dalam memberikan pelayanan. Dalam jaminan kepastian ketepatan waktu pelayanan pun dapat terpenuhi, sehingga apabila waktu tutup pelayanan, perpustakaan keliling akan menutup pelayanannya sesuai dengan jadwal yang ada. Selain itu, dalam jaminan biaya pun, Dinas Perpustakaan dan Kearsipan Kabupaten Kotawaringin Timur telah menjamin pengunjung dapat memanfaatkan jasa layanan perpustakaan keliling dengan gratis.

\section{e. Emphaty (Empati)}

Pada dimensi emphaty mencakup kepedulian petugas berkaitan dengan pemberian perlakuan penuh perhatian kepada pengunjung. Aminullah \& Rifqoh, (2021) menjelaskan bahwa dimensi empati mempunyai peran penting untuk mengukur dari suatu kualitas pelayanan, hal tersebut dikarenakan sikap baik yang diberikan petugas dapat menciptakan rasa aman dan nyaman pengunjung terhadap dinas atau instansi yang 
bersangkutan. Hasil penelitian yang dilakukan peneliti melihat bahwa Pengunjung perpustakaan keliling Dinas Perpustakaan dan Kearsipan Kabupaten Kotawaringin Timur merasa telah mendapatkan perlakuan penuh perhatian dengan adanya petugas yang memberikan respon baik dan ramah kepada pengunjung yang hendak mengetahui lebih banyak mengenai informasi perpustakaan maupun koleksi buku baru perpustakaan. Selain itu juga, apabila terdapat keluhan maupun saran terkait pelayanan, petugas dapat mendengarkannya dan menerima keluhan dan saran tersebut dengan seksama yang kemudian petugas catat sebagai bahan evaluasi pelaksanaan layanan perpustakaan.

Di lain hal, penurunan jumlah pengunjung pada perpustakaan juga terjadi dikarenakan jumlah kunjungan pengunjung dalam bentuk rombongan terhitung tidak sebanyak pada tahun 2018. Namun di luar hal tersebut, berbagai upaya mereka lakukan untuk menjamin kepuasan pengunjung perpustakaan keliling, petugas secara cepat dan tepat membantu pengunjung yang merasa kesulitan atau kebingungan, kemampuan dan keramahan petugas yang baik dalam menjalankan tugasnya, bersikap dengan ramah kepada pengunjung membuat pengunjung merasa nyaman dan gembira dalam melakukan kegiatan di perpustakaan keliling.

\section{KESIMPULAN}

Berdasarkan hasil dan pembahasan penelitian diatas jika dilihat dari dimensi kualitas pelayanan publik oleh Zeithaml, Parasuraman, dan Berry dalam (Arista, 2019). Kualitas Pelayanan Perpustakaan Keliling di Dinas Perpustakaan dan Kearsipan Kabupaten Kotawaringin Timur dapat dikatakan sudah cukup baik yang meliputi yaitu:

1. Tangibles (Bukti Fisik) dimensi ini yang mencakup sarana serta prasarana yang disediakan dapat dikatakan belum cukup baik, sehingga ada beberapa hal yang harus diperbaiki yaitu perlunya tenda, kursi dan meja baca serta kurang tersedianya komputer untuk mempermudah pekerjaan petugas, dan kurang lengkapnya koleksi buku yang tersedia untuk pengunjung.

2. Reliability (Kepercayaan) dimensi ini mencakup kemampuan dan kehandalan petugas dalam menyediakan pelayanan yang terpercaya sudah cukup baik, hanya saja masih kurangnya pustakawan, prosedur meminjam buku yang harus mendatangi dinas perpustakaan terlebih dahulu, serta wawasan petugas perpustakaan mengenai pelayanan perpustakaan masih mengalami beberapa kendala, hal itu terjadi karena masih kurangnya pendidikan dan pelatihan petugas secara intensif dalam bidang perpustakaan.

3. Responsiveness (Daya Tanggap) mencakup ketanggapan dan kepedulian petugas perpustakaan dapat dikatakan sudah baik. Hal itu dapat dibuktikan dengan kecepatan petugas dalam merespon pertanyaan atau permintaan yang diajukan oleh pengunjung 


\section{Journal Publicuho}

ISSN2621-1351 (online), ISSN 2685-0729 (print)

Volume 4 Number 2 (May-July), (2021)pp. 400-410

Accredited SINTA SK.NOMOR 28/E/KPT/2019

Open Access at:http://ojs.uho.ac.id/index.php/PUBLICUHO/index DOI: 10.35817/jpu.v4i2.18049

mengenai permintaan pendaftaran atau referensi buku. Namun yang menjadi kendala adalah tidak tersedianya komputer untuk mempermudah pelayanan petugas.

4. Assurance (Jaminan) dimensi dimana mencakup kemampuan dan keramahan petugas dalam pelayanan perpustakaan keliling sudah dapat dikatakan baik. Hal tersebut terbukti dalam melayani pengunjung petugas perpustakaan keliling memberikan ekspresi yang ramah, sopan dan menyenangkan sehingga menimbulkan persepsi positif kepada pengunjung.

5. Emphaty (Empati) terkait dengan kepedulian petugas kepada pengunjung sudah sangat baik karena petugas memberikan respon yang baik, selain itu petugas juga menerima keluhan dan saran dari pengunjung sebagai bahan evaluasi pelaksanaan layanan perpustakaan.

Dari hasil dan pembahasan diatas, dapat di simpulkan bahwa pelayanan yang diberikan perpustakaan keliling kepada masyarakat sudah cukup baik, namun tetap ada perlunya perbaikan terkait dimensi tangibles (bukti fisik) dan dimensi reliability (kepercayaan) agar pengunjung yang datang dapat lebih nyaman.

\section{REFERENSI}

Agitia, D. (2019). "Akuntabilitas Pelayanan Publik Dalam Program E-Ktp Di Tingkat Pemerintahan Daerah Pada Dinas Kependudukan Dan Pencatatan Sipil Kabupaten Malang". Jurnal IImu Sosial dan IImu Politik, 8(2), 122-127.

Aminullah, A., \& Rifqoh, I. (2021). Kualitas Pelayanan Publik Dalam Mekanisme Pelayanan Kartu Keluarga Di Kecamatan Purwosari Kabupaten Pasuruan. Journal Publicuho, 4 (1), 78. https://doi.org/10.35817/jpu.v4i1.16233

Yuningsih, R. (2016). Kualitas Pelayanan Publik Di Kantor Perwakilan Pemerintah Daerah Kabupaten Tolitoli Di Kota Palu. Katalogis, 4(8), 175-183.

Arif, L. (2019). "Kualitas Pelayanan Balai Pemberantasan Dan Pencegahan Penyakit Paru Di Pamekasan". Jurnal Dinamika Governance FISIP UPN "Veteran" Jatim, 9(1)

Arista, R. (2019). "Kualitas Pelayanan Perpustakaan Daerah Kabupaten Subang". Jurnal IImiah IImu Administrasi Negara, 6(4).

Ariyani, A., Lely, I. M., \& Mohammad, N. (2016). "Inovasi Pelayanan Publik (Studi pada Pelayanan Kesehatan Melalui Program Gebrakan Suami Siaga di Puskesmas Gucialit Kabupaten Lumajang)". Jurnal IImiah Administrasi Publik (JIAP), 2(4).

Akmala, N. H., \& Jazimatul, H. (2017). "Pemanfaatan Layanan Perpustakaan Keliling "Ruang Terbuka Hijau" Sebagai Sarana Promosi Menumbuhkan Minat Baca Di Dinas Perpustakaan Dan Kearsipan Kabupaten Pemalang". Jurnal Ilmu Perpustakaan, 6(4). 
Evans, S. A. (2019). "“Book Nerds" United: The Reading Lives of Diverse Adolescents at the Public Library". The International Journal of Information, Diversity, \& Inclusion (IJIDI), 3(2).

Koertriana, P. L., \& Amin, R. M. (2017) "Pelayanan Publik Urusan Pemerintahan Daerah Bidang Kependudukan dan Pencatatan Sipil Kota Pekanbaru Tahun 2014 (Studi Pengurusan Surat Keterangan Datang)". Jurnal Online Mahasiswa (JOM) Bidang IImu Sosial dan Ilmu Politik, 4(1).

Kolianan, J. B., Aloysius, L., \& Lenny, T. (2016). "Strategi Media Relations Humas Dalam Meningkatkan Kualitas Pelayanan Keluarga Berencana (KB) Pada Badan Kependudukan Dan Keluarga Berencana Nasional (BKKBN) Provinsi NTT". Jurnal Administrasi Publik, 6(1)

K., B. C., \& Mecca, A. (2017). "Pengaruh Kualitas Pelayanan Terhadap Kepuasan Pemustaka Di Perpustakaan Stikes Telogorejo Semarang". Jurnal Ilmu Perpustakaan, 6(3).

Laksmi, L. (2020). "Strategi Perpustakaan Menerapkan Literasi Untuk Meningkatkan Imajinasi, Kreativitas, Inovasi". Jurnal Sosial Keagamaan, 4(1), 12-24.

La Ode Muhammad Elwan. (2019). PROBLEM BIROKRASI DALAM MENINGKATAN PELAYANAN

PUBLIK PADA SEKRETARIAT DAERAH KABUPATEN MUNA. In Copyright@2019 Journal

PUBLICUHO Faculty of Social and Political Sciences Halu Oleo University (Vol. 2).

Retrieved from http://ojs.uho.ac.id/index.php/PUBLICUHO

Melinda, M., "Syamsurizaldi, \& Muhammad, I. K. (2020). Inovasi Pelayanan Administrasi Kependudukan Online (PADUKO) oleh Dinas Kependudukan dan Pencatatan Sipil Kota Padang Panjang". Jurnal Ilmu Pemerintahan, 19(2).

Puslitjakbud. (2019). "Indeks Aktivitas Literasi Membaca 34 Provinsi. Jakarta: Pusat Penelitian Kebijakan Pendidikan dan Kebudayaan, Badan Penelitian dan Pengembangan, Kementerian Pendidikan dan Kebudayaan".

Salsabila, A. K., \& Ertien, R. N. (2019). "Inovasi Pelayanan Simpadu-Pmi Dalam Meningkatkan Kualitas Pelayanan (Unit Pelaksana Teknis Pelayanan Dan Perlindungan Tenaga Kerja Indonesia (UPT P2TK) Provinsi Jawa Timur)". Public Administration Journal, 2(7) 